\title{
Protozoan impact on bacterial biofilm formation
}

\author{
KRZYSZTOF RYCHERT ${ }^{1}$ and THOMAS R. NEU ${ }^{2}$ \\ ${ }^{1}$ Department of Aquatic Ecology, Pomeranian University in Słupsk, Arciszewskiego 22b, \\ 76-200 Słupsk, Poland \\ ${ }^{2}$ Department of River Ecology, Helmholtz Centre for Environmental Research - UFZ, \\ Brückstrasse 3A, 39114 Magdeburg, Germany \\ Corresponding author: Krzysztof Rychert, krychert@wp.pl
}

(Received on 21 July 2009; Accepted on 7 April 2010)

\begin{abstract}
Confocal laser scanning microscopy in combination with digital image analysis was used to assess the impact of protozoa on bacterial colonisation of surfaces. Bacterial biofilms were developed from activated sludge in microscope flow cells and were exposed to the grazing pressure of protozoa. The protozoan community from healthy activated sludge and a culture of flagellate Bodo saltans were used as grazers. Experiments comprised 48-h incubations in 3 treatment variants: bacteria with protozoa, bacteria with protozoa added after some time and bacteria without protozoa. When necessary, the elimination of protozoa from the inoculum was carried out with cycloheximide and $\mathrm{NiSO}_{4}$. Experiments demonstrated that protozoa from healthy activated sludge initially disturbed the biofilm development but later they could stimulate its growth. Similar results could be established in the experiment with Bodo saltans (inoculum: $1000 \mathrm{cell} / \mathrm{s} / \mathrm{ml}$ ), however differences were not statistically significant. The finding that protozoa support biofilm development during specific stages may be relevant for biofilm studies with mixed environmental biofilm communities.
\end{abstract}

Keywords: biofilm, protozoa, grazing, activated sludge

\section{INTRODUCTION}

Most bacteria in nature grow associated with interfaces (HALL-STOOdLEY et al. 2004). Consequently the metabolism of microbial biofilms plays a crucial role in the decomposition of organic matter on the global scale. Both free-swimming and attached bacteria are grazed by protozoa and protozoa shape the composition and activity of the bacterial community. Grazing on suspended bacteria is generally wellstudied, whereas there is a lack of analogous studies of protozoan grazing on biofilms. This is mainly due to the need of more sophisticated methods when studying grazing on microbial biofilms. Authors of available literature on this subject (e.g. PEDERSON 1990; Jackson \& Jones 1991; Lawrence \& SNyder 1998; Sibille et al. 1998; Weitere et al. 2005; PARRY et al. 2007; MATZ et al. 2008) used light and epifluorescence micros- 
copy, confocal laser scanning microscopy, and ultrasonic imaging. Apart from general information about grazing rates of particular protozoan species and preliminary data on their ability to engulf weakly or strongly attached bacteria, there is a deficiency of studies on the shaping impact of protozoa on biofilms (PARRY 2004).

The aim of this study was to assess the impact of protozoa on formation and early stage of growth $(48 \mathrm{~h})$ of attached microbial communities. Parallel biofilms were developed from activated sludge with and without grazing pressure. As grazers, a natural community of protozoa from healthy activated sludge or the flagellate Bodo saltans Ehrenberg 1830 were used. After incubation, the biovolume of the bacterial biofilms from different treatments was assessed by confocal laser scanning microscopy (CLSM) in combination with digital image analysis.

\section{MATERIALS AND METHODS}

Grazing experiments were conducted on biofilms developed in flow-through cells, each composed of 3 separate flow lanes (RAmos et al. 2001). Bacteria grew on the cover glass of the flow cell. The experimental system comprised a few devices connected with silicone tubings and was arranged as follows: reservoir with medium, tube splitter (1 into 3), peristaltic pump (Watson Marlow), bubble traps (3), tube splitters (3), flow cells (3, with 9 lanes altogether), and about 1-m-long terminal tubings. Prior to experiments, the system was cleaned and disinfected with bleach (sodium hypochlorite $0.5 \%$, exposure lasting $4 \mathrm{~h}$ or overnight). After disinfection, hypochlorite was washed with autoclaved, demineralised water. To develop the biofilms, we used a rich medium, R2A (REASONER \& GELDREICH 1985). Just before the start of the experiment, a bottle with sterile medium was aseptically connected to the system and the entire system was filled with medium. Bacteria from activated sludge were used as inoculum. In some treatments bacteria were accompanied by protozoa from healthy sludge or by an artificially added culture of Bodo saltans Ehrenberg 1832. Inocula were injected to flow cells with a syringe equipped with a needle. After inoculation lasting $30 \mathrm{~min}$ (without medium flow), the medium was pumped through the experimental system at a rate of $0.2 \mathrm{~mm} / \mathrm{s}$. After running the experiment for $48 \mathrm{~h}$ at room temperature, the biofilms were stained (see below) and inspected by means of confocal laser scanning microscopy (CLSM).

Activated sludge used as inoculum originated from the wastewater treatment plant in Magdeburg (Germany). It was taken in April 2005 and immediately used in experiment I. Additionally, a number of aliquot vials with sludge were frozen $\left(-20^{\circ} \mathrm{C}\right)$ and used in experiments II and III after thawing overnight at $4^{\circ} \mathrm{C}$. Both fresh and frozen sludge contained bacteria and protozoa. Inspection done under a light microscope revealed a mixed protozoan community composed of ciliates, amoebae and small flagellates (few $\mu \mathrm{m}$ in size). Both attached ciliates (peritrichs) and crawling ones (scuticociliates and hypotrichs) were observed. Before injection, the inocula were centrifuged to remove flocs (at $26 \mathrm{~g}$ for 5 minutes), and the supernatant was moved to new Eppendorf tubes. When necessary, protozoa were excluded from the sludge as follows. Sludge was centrifuged once again (at $800 \mathrm{~g}$ for 10 minutes), the supernatant 
was discharged, and the pellet resuspended in $1 \mathrm{ml}$ of sterile saline solution $(0.85 \%$ $\mathrm{NaCl}$ ) containing cycloheximide (final concentration: $250 \mathrm{mg} / \mathrm{ml}$ ) and $\mathrm{NiSO}_{4}$ (final concentration: $0.1 \% \mathrm{w} / \mathrm{v}$ ) (SCHEUERMAN et al. 1988). After $12 \mathrm{~h}$, the inoculum was washed with saline solution ( 3 centrifugations at $1050 \mathrm{~g}$ for 5 minutes each), and finally resuspended in $1 \mathrm{ml}$ of saline solution. No protozoa were observed on biofilms developed from those inocula.

The third experiment was carried out with Bodo saltans strain HFCC12. The flagellate was kept in soil/water biphasic medium prepared according to Culture Collection of Algae and Protozoa, Argyll, UK (www.ccap.ac.uk) and fed with bacteria co-occurring in the medium. For inoculation, a dilution (with sterile medium) containing about 1000 cells $/ \mathrm{ml}$ was prepared. Abundance of flagellates was determined with the Utermöhl method (UTERMÖHL 1931).

Before observation, bacteria were stained with Syto9 (Molecular Probes) and protozoa were counterstained with CellTrackerRed (Molecular Probes). Syto9 was diluted, stored and used according to the guidelines of the supplier. CellTrackerRed was diluted in DMSO and water (final concentration used for staining: $2 \mu \mathrm{M}$ ). Due to the use of a point-scanning CLSM instrument, protozoa were immobilised with $\mathrm{NiSO}_{4}$ (final concentration: $0.01 \%$ ) (PACKROFF et al. 2002). Dyes and $\mathrm{NiSO}_{4}$ were mixed together and injected to flow cells. Observations of biofilms were carried out inside flow cells, using a Leica TCS-4D confocal laser scanning microscope equipped with argon-krypton laser. Images were recorded using the $63 \times 1.2$ water-immersible objective lens. Optical sections were taken at $1-\mu \mathrm{m}$ intervals. Images were acquired in 2 channels simultaneously, for Syto9 (green fluorescence) and CellTracker (red fluorescence). Images were analysed using ConAn software, specially developed for Helmholtz Centre for Environmental Research - UFZ by BioCom. On the basis of Syto9 signals, the bacterial biomass (assessed as biovolume) for randomly taken areas (ca. $25000 \mu \mathrm{m}^{2}$ each) was assessed. For every treatment 5-7 areas, originated from three replicate flow lanes, were analysed. Differences between treatments were tested with ANOVA and post hoc Tukey test. All calculations were done in Statistica (StatSoft).

\section{RESULTS}

Application of a rich R2A medium caused prevalence of bacterial growth over their grazing loses. Consequently, biofilm growth was observed in all treatments (with and without protozoa). Biofilms grew unevenly. Those developed from fresh inoculum (experiment I, after $48 \mathrm{~h}$ ) were locally up to $30 \mu \mathrm{m}$ thick, but mean thickness was 2-7 $\mu \mathrm{m}$. When frozen inoculum was used (experiments II and III), the mean biofilm thickness did not exceed $3 \mu \mathrm{m}$. No characteristic developmental structures, such as microcolonies were observed. Protozoa in frozen inocula were less abundant.

The impact of protozoa on bacterial growth was assessed as a difference in bacterial biomass observed after incubation in the presence and in the absence of protozoa. Experiments I and II were carried out with organisms from activated sludge only (Fig. 1). In these experiments three simultaneous treatments were run. Biofilms in 


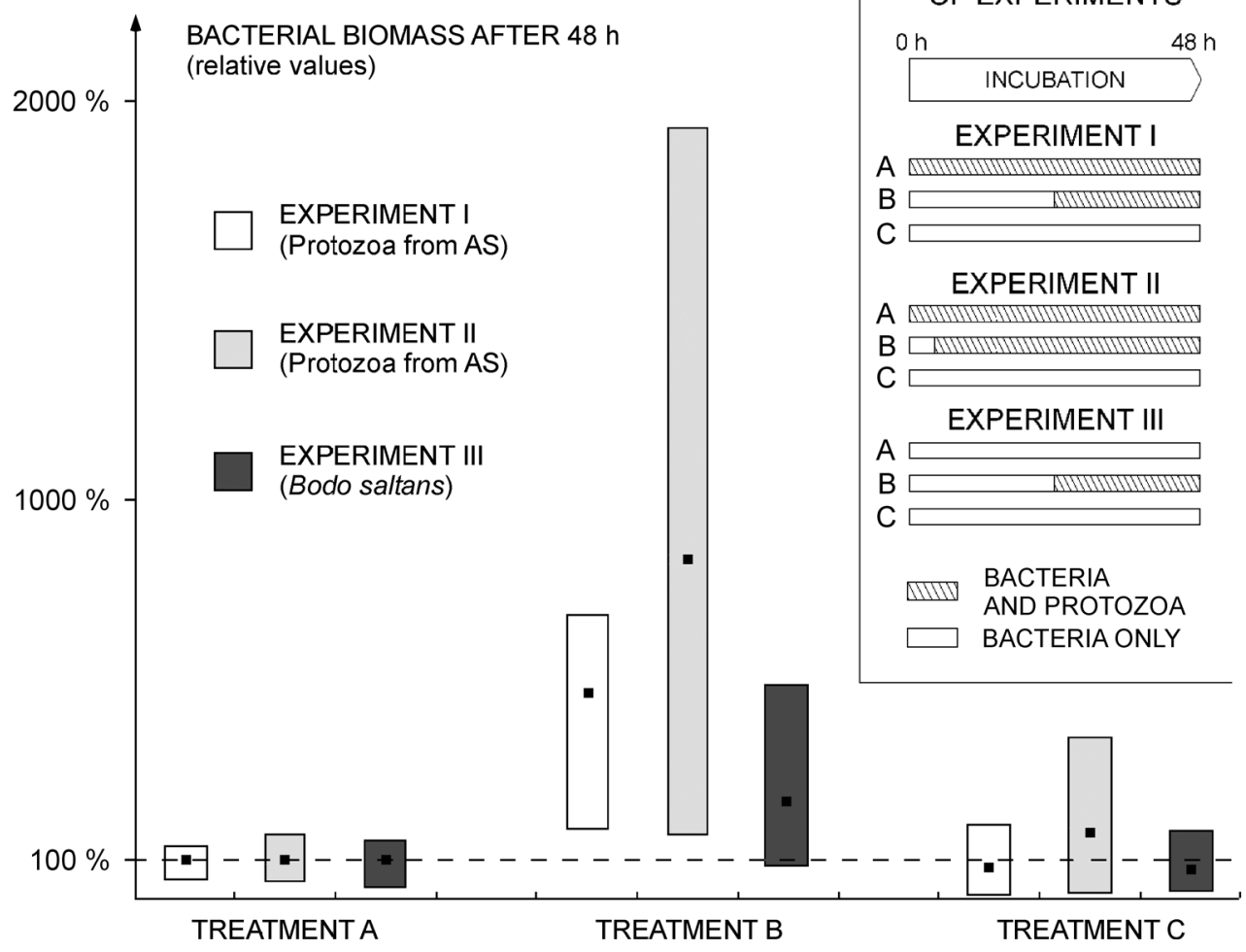

Fig. 1. Biomass of bacterial biofilm (expressed as biovolume) developed during incubation with and without protozoan grazers. In all experiments the bacterial biofilm was developed from activated sludge (AS). Bars and black squares inside them show ranges and mean values of biofilm biomass, respectively. Results for treatments B and $\mathrm{C}$ were standardised according to the mean value of treatment A (treated as $100 \%$ )

treatment A were developed from non-manipulated inoculum containing both bacteria and protozoa. In treatment B biofilm initially grew without protozoa, which were excluded from inoculum. Later on, protozoa were reintroduced by using non-manipulated inoculum. In the last treatment $(\mathrm{C})$ only bacteria were inoculated. In experiment I, inocula originated from fresh activated sludge, and reintroduction of protozoa in treatment B took place after $24 \mathrm{~h}$. In experiment II, frozen activated sludge was used and protozoa were reintroduced after $4 \mathrm{~h}$ of incubation. Incubations in both experiments lasted $48 \mathrm{~h}$. Simultaneously, with reintroduction of protozoa in treatment $\mathrm{B}$, additional protozoan-deprived inoculum was injected to the biofilm grown without protozoa (treatment $\mathrm{C}$ ). This was done to decrease the possible effect of addition of bacteria present in all inocula. Moreover, the incubation time of the second inoculation was shortened from $30 \mathrm{~min}$ to $10 \mathrm{~min}$. As protozoan mobility exceeds bacterial mobility, short inoculation time restricted mostly bacterial attachment. 
As presented in Fig. 1, incubation of bacteria with protozoa (treatment A) and bacteria without protozoa (treatment $\mathrm{C}$ ) resulted in comparable development of biofilms. The highest bacterial growth was observed in treatments B (initial stage - protozoa removed, later stage - protozoa present). In experiments I and II, bacterial growth in treatment B was significantly higher than in treatments A and C (Table 1). Such results could be explained as co-occurrence of 2 different effects: (i) disruption (by protozoa) of bacterial surface colonisation (treatment A versus B) and (ii) stimulation of further growth of the biofilm (treatment B versus C).

In experiment III, a biofilm was also developed from activated sludge, but Bodo saltans was used as a grazer. All 3 flow cells (treatments) were inoculated with bacteria only. In treatments $\mathrm{B}$ and $\mathrm{C}$ after $24 \mathrm{~h}$ (i.e. in the middle of incubation), additional inoculum was added: Bodo saltans with accompanying bacteria to treatment $\mathrm{B}$ and bacteria from Bodo saltans culture (but without flagellates) to treatment C (control). Like in experiments I and II, the presence of flagellates stimulated biofilm development (Fig. 1). Unfortunately, the differences in experiment III were not statistically significant (Table 1).

Table 1. Statistical analysis of the experiments. Because variances were not homogeneous, results were logarithmically transformed. Statistically significant results are boldfaced

\begin{tabular}{cccc}
\hline \multirow{2}{*}{ Experiment } & \multicolumn{2}{c}{ ANOVA } & \multicolumn{2}{l}{ Post hoc Tukey test } \\
\hline I & $\boldsymbol{F}=\mathbf{1 0 . 1}, \boldsymbol{N}=\mathbf{1 5}, \boldsymbol{P}=\mathbf{0 . 0 0 3}$ & A-B & $\boldsymbol{P}=\mathbf{0 . 0 2 3}$ \\
& & A-C & $P=0.506$ \\
II & B-C & $\boldsymbol{P}=\mathbf{0 . 0 0 4}$ \\
& A-B & $\boldsymbol{P}=\mathbf{0 . 0 0 8}$ \\
& & A-C & $P=0.964$ \\
III & B-C & $\boldsymbol{P}=\mathbf{0 . 0 1 3}$ \\
& $F=3.48, N=15, P=0.064$ & - & - \\
\hline
\end{tabular}

Staining of eukaryotic cells with CellTracker allowed observation of protozoan grazers, such as hypotrich ciliates, amoebae, and flagellates. Their closer identification was impossible because CellTracker did not visualise features of taxonomic importance. Moreover, immobilisation of protozoa (before CLSM) resulted in the removal of a large fraction of protozoa from the biofilm surface. The majority of cells were detached from the biofilm by liquid current and were detected at the end of a flow lane. Some of them probably drifted outside the flow cells (into tubings). 
As a consequence their quantification was impossible. Staining during experiment III revealed only few cells of Bodo saltans.

\section{DISCUSSION}

The experiments demonstrated that protozoa disturbed the initial biofilm development but in a later stage they could stimulate biofilm growth. Experiment III (with Bodo saltans) gave a similar result but the differences were not statistically significant. This could be partially explained by the fact that Bodo saltans typically feeds on free-swimming (suspended) bacteria (PARRY 2004).

It is difficult to define conditions promoting grazing-stimulated biofilm growth. The main difficulty is the use of an inoculum containing many different bacterial strains. The biofilms were, most probably, composed of $\gamma$-proteobacteria, because this group is promoted by R2A medium (BöCKELMANN et al. 2000). Mixed composition of developed biofilms was indirectly indicated by a large variance of bacterial biovolume in treatment B (Fig. 1). However, there is also an alternative explanation: methodological difficulty of adding a defined number of protozoa from natural communities (experiments I and II). Well-defined biofilms would be better for quantitative studies on interactions between biofilm and bacterivores.

In experiments I and II, also the composition of the protozoan community remained poorly characterised. It was mainly a consequence of their removal from the biofilm after immobilisation, and limited taxonomic information provided by CLSM. It is also possible that some protozoa could lyse after addition of $\mathrm{NiSO}_{4}$ or were not stained with CellTracker (PACKROFF et al. 2002). Quantitative analyses of protozoa require other strategies, e.g. in terms of the experimental setup, application of special imaging techniques, or an improved method of immobilisation.

More vigorous growth of the biofilm under the grazing pressure seems to contradict common sense. Many studies reported that protozoa reduced biofilm development (e.g. Huws et al. 2005). However, it was also widely reported that in wastewater treatment plants and in natural aquatic environments, protozoa could enhance bacterial growth (e.g. Ratsak et al. 1996; Pernthaler et al. 1997). Sieburth et al. (1982) and Sherr et al. (1986) demonstrated that such stimulation could be caused by release of nutrients or excretion of labile organic compounds. However, PARRY (2004) concluded in her review that the importance of such nutrient remineralisation decreases with an increase in trophic state. This indicates that remineralisation was rather unimportant, due to the medium used during experiments (rich in mineral and organic compounds) and small thickness of developed biofilms (non-restricting penetration of nutrients). Other explanations of the observed stimulation could be non-selective grazing and bacterial response to grazing pressure. Non-selective elimination of bacteria leads to the domination of faster-growing bacterial strains (COLE 1999), whereas some strains of bacteria, being under grazing pressure, are able to increase their growth rates and even outgrow predators (PERNTHALER et al. 1997). Further studies on protozoan selective feeding and dynamics of bacterial growth need to (i) resolve the biofilm composition (with gene probes) and (ii) compare bacteria constituting the biofilm 
and those inside protozoa (grazed). In this study the observation of bacteria inside protozoa (grazed) was difficult, as many protozoa were removed from the biofilm. Gene probes developed for natural protozoan communities could be also an option for improvement of taxonomic identification of protozoa under CLSM.

Acknowledgements: We thank Ute Kuhlicke for help with operating the confocal microscope. The supply of protozoan cultures by Anja Scherwass (University of Cologne, Germany) and comments of anonymous reviewers are also appreciated. K. Rychert was supported by the EC Marie Curie Programme (HPMT-CT-2001-00426).

\section{REFERENCES}

Böckelmann U., Manz W., Neu T., Szewzyk U. 2000. Characterization of microbial community of lotic organic aggregates ('river snow') in the Elbe River of Germany by cultivation and molecular methods. FEMS Microbiol. Ecol. 33: 157-170.

Cole J. 1999. Aquatic microbiology for ecosystem scientists: new and recycled paradigms in ecological microbiology. Ecosystems 2: 215-225.

Hall-Stoodley L., Costerton J. W., Stoodley P. 2004. Bacterial biofilms: from the natural environment to infectious diseases. Nat. Rev. Microbiol. 2: 95-108.

Huws S. A., McBain A. J., GilberT P. 2005. Protozoan grazing and its impact upon population dynamics in biofilm communities. J. Appl. Microbiol. 98: 238-244.

JACKSON S. M., JONES E. B. G. 1991. Interactions within biofilms: the disruption of biofilm structure by protozoa. Kieler Meeresforsch. Sonderh. 8: 264-268.

LAWRENCE J. R., SNYDER R. A. 1998. Feeding behaviour and grazing impacts of a Euplotes sp. on attached bacteria. Can. J. Microbiol. 44: 623-629.

Matz C., Webb J. S., Schupp P. J., Phang S. Y., Penesyan A., Egan S., Steinberg P., KJelleberg S. 2008. Marine biofilm bacteria evade eukaryotic predation by targeted chemical defence. PloS ONE 3: e2744.

Packroff G., Lawrence J. R., Neu T. R. 2002. In situ confocal laser scanning microscopy of protozoans in cultures and complex biofilm communities. Acta Protozool. 41: 245-253.

Parry J. D. 2004. Protozoan grazing of freshwater biofilms. Adv. Appl. Microbiol. 54: 167-196.

Parry J. D., Holmes A. K., Unwin M. E., Laybourn-Parry J. 2007. The use of ultrasonic imaging to evaluate the effect of protozoan grazing and movement on the topography of bacterial biofilms. Lett. Appl. Microbiol. 45: 364-370.

Pederson K. 1990. Biofilm development on stainless steel and PCV surfaces in drinking water. Water Res. 24: 239-243.

Pernthaler J., Posch T., Šimek K., Vrba J., Amann R., Psenner R. 1997. Contrasting bacterial strategies to coexist with a flagellate predator in an experimental microbial assemblage. Appl. Environ. Microbiol. 63: 596-601.

Ramos C., Licht T. R., Sternberg C., Krogfelt K. A., Molin S. 2001. Monitoring bacterial growth activity in biofilms from laboratory flow chambers, plant rhizosphere, and animal intestine. Methods Enzymol. 337: 21-42.

Ratsak C. H., Maarsen K. A., Kooljman S. A. L. M. 1996. Effects of protozoa on carbon mineralization in activated sludge. Water Res. 30: 1-12.

Reasoner D. J., Geldreich E. E. 1985. New medium for the enumeration and subculture of bacteria from potable water. Appl. Environ. Microbiol. 49: 1-7.

Scheuerman P. R., Schmidt J. P., Alexander M. 1988. Factors affecting the survival and growth of bacteria introduced into lake water. Arch. Microbiol. 150: 320-325. 
Sherr B. F., Sherr E. B., Andrew T. L., Fallon R. D., Newell S. Y. 1986. Trophic interactions between heterotrophic protozoa and bacterioplankton in estuarine water analysed using selective metabolic inhibitors. Mar. Ecol. Prog. Ser. 32: 169-180.

Sibille I., Sime-Ngando T., Mathieu L., Block J. C. 1998. Protozoan bacterivory and Escherichia coli survival in drinking water distribution systems. Appl. Environ. Microbiol. 64: 197-202.

Sieburth J. M., Davis P. G. 1982. The role of heterotrophic nanoplankton in the grazing and nurturing of planktonic bacteria in the Sargasso and Caribbean Seas. Ann. Inst. Oceanogr. Paris 58 (S): 285-296.

UtermöHL H. 1931. Neue Wege in der quantitativen Erfassung des Planktons. Verh. Int. Ver. Theor. Angew. Limnol. 5: 567-596.

Weitere M., Bergfeld T., Rice S. A., Matz C., Kuellenberg S. 2005. Grazing resistance of Pseudomonas aeruginosa biofilms depends on type of protective mechanism, developmental stage and protozoan feeding mode. Environ. Microbiol. 7: 1593-1601. 